\title{
Habitat use patterns of franciscana dolphins (Pontoporia blainvillei) off southern Brazil in relation to water depth
}

\author{
DANIEL DANILEWICZ ${ }^{1,6}$, EDUARDO R. SECCHI ${ }^{2,6}$, PAULO H. OTT ${ }^{1,3,6}$, IGNACIO B. MORENO ${ }^{1}$, \\ MANUELA BASSOI ${ }^{2,4,6}$ AND MÁRCIO BORGES-MARTINS ${ }^{1,5}$ \\ ${ }^{1}$ Grupo de Estudos de Mamíferos Aquáticos do Rio Grande do Sul (GEMARS), Rua Felipe Neri, 382/203, Porto Alegre 90440-150, \\ Brazil, ${ }^{2}$ Laboratory of Marine Mammals, Museu Oceanográfico 'Prof. Eliézer C. Rios', Universidade Federal do Rio Grande, \\ Cx P 379, CEP 96200, Rio Grande, Brazil, ${ }^{3}$ Universidade Estadual do Rio Grande do Sul (UERGS), Cidreira, Rio Grande do Sul, \\ Brazil, ${ }^{4}$ National Oceanography Centre, Southampton, European Way, SO14 3ZH, Southampton, UK, ${ }^{5}$ Departamento de \\ Zoologia, Universidade Federal do Rio Grande do Sul, Brazil, ${ }^{6}$ Grupo de Ecologia e Conservação de Megafauna Marinha-EcoMega
}

\begin{abstract}
The patterns of habitat use by the franciscana dolphins (Pontoporia blainvillei) along its distribution are poorly known. This study investigates the patterns of habitat use with respect to depth for 181 individuals of different age, size, gender and reproductive condition off Rio Grande do Sul, southern Brazil. The results reveal that franciscanas are very homogeneously distributed according to depth. Individuals from all lengths utilize nearly the entire range of depths of the surveyed area. Larger or older animals do not use deeper waters than younger animals, indicating that body size and age are not limiting factors for franciscanas that occupy deeper or offshore waters. Gestation seems to not cause a change in the distribution of females. Although the sex-ratio of the overall data did not vary from 1:1 in different depth intervals, a small-scale comparison between the northern and southern coast demonstrated the existence of some kind of sexual segregation. Franciscana by-catch in Rio Grande do Sul is not sustainable and it is agreed that management procedures are needed. Nevertheless, the available data on species distribution do not allow the designing of a protected area in order to minimize the by-catches of a particular sex/reproductive class.
\end{abstract}

Keywords: habitat use, Pontoporia blainvillei, southern Brazil, water depth, incidental catches, sex-ratio

Submitted 15 October 2008; accepted 29 January 2009; first published online 15 May 2009

\section{INTRODUCTION}

The franciscana, Pontoporia blainvillei, is a small dolphin endemic to shallow, coastal waters of tropical and temperate regions along the coasts of Brazil, Uruguay and Argentina (Crespo et al., 1998; Siciliano et al., 2002). Although it has been considered to be a member of the so-called river dolphins, franciscanas are found mainly in coastal marine waters with occasional occurrences in estuaries, being relatively common on the La Plata River estuary (Praderi, 1986; Rodriguez et al., 2002).

The preference for coastal waters makes the species vulnerable to the human activities. Incidental catches in fishing gears, especially gillnets and trammel nets, have been reported throughout its range, and the franciscana has been regarded as the most endangered small cetacean of the south-western Atlantic Ocean (Secchi et al., 2003a). On the coast of Rio Grande do Sul, southern Brazil, this species has been experiencing an intense by-catch in gillnets for at least three decades (Praderi et al., 1989; Moreno et al., 1997; Secchi et al., 1997a; Ott et al., 2002). The annual mortality of franciscanas in this region was estimated to be ranging from several

Corresponding author:

D. Danilewicz

Email: daniel.danilewicz@gmail.com hundreds up to around one thousand individuals (Secchi et al., 1997a, 2004; Ott, 1998; Ott et al., 2002). The estimated mortality rates outnumber the potential rate of population increase, suggesting that a population decline is likely due to persisting levels of human-induced mortality (Secchi, 2006). For this reason, the population inhabiting the coast of Rio Grande do Sul and Uruguay (Franciscana Management Area III, see Secchi et al., 2003b) has been recently classified as Vulnerable by the IUCN Red List of Threatened Species (IUCN, 2008).

Due to the species avoidance of engine-powered boats, its small size, its inconspicuous colour pattern, and small group size, sightings of franciscanas in the wild are very rare. The only locations where franciscanas have been sighted regularly are some bays in Argentina and southern Brazil (Bordino, 2002; Cremer \& Simões-Lopes, 2005). Presenting a very distinct situation of these localities, the Rio Grande do Sul coast is composed of almost continuous sandy beaches along $620 \mathrm{~km}$, with no bay or inlet with protected waters. Although more than 150 surveys were made by experienced marine mammal researchers, onboard engine-powered fishing boats in this area to verify marine mammal-fishery interactions, no free-swimming franciscana were sighted. Surprisingly, levels of by-catch are high in the area (e.g. Ott et al., 2002).

The patterns of habitat use by the franciscana are poorly known. Past studies of incidental catches along the southern 
portion of its range (Uruguay and southern Brazil) have indicated that the species is distributed mainly to a maximum depth of $30 \mathrm{~m}$, which usually corresponds to a distance of about 25-30 nautical miles from the coast (Pinedo et al., 1989; Moreno et al., 1997; Secchi et al., 1997a). Two previous studies that analysed the franciscana by-catch locations have proposed the existence of some degree of spatial segregation by water depth for the species (Secchi et al., 1997b; Rosas et al., 2002). However, little is still known how animals of different sexes, age, size or reproductive status are distributed within the species-range, or whether there is or not any sort of segregation among them. Such information is certainly essential to design a management plan for this vulnerable population.

This study was outlined to meet some of these shortcomings on the habitat use patterns of franciscanas. The hypothesis of a differential distribution in water depth is tested. Latitudinal variation to the northern and southern coast of Rio Grande do Sul, on the sex-ratio was also tested for incidentally caught franciscanas.

\section{MATERIALS AND METHDDS}

\section{Sampling procedures}

Biological and location data from 181 (107 males and 74 females) franciscanas incidentally caught by the coastal gillnetters operating off Rio Grande do Sul, southern Brazil were considered in this study. A portion of the fishing fleets operating from Tramandaí/Imbé $\left(29^{\circ} 58^{\prime} \mathrm{S} 50^{\circ} 07^{\prime} \mathrm{W}\right)$ and Rio Grande $\left(32^{\circ} 08^{\prime} \mathrm{S} 52^{\circ} 05^{\prime} \mathrm{W}\right)$ was monitored between 1993 and 1998 for the recovery of incidentally caught franciscanas. Onboard surveys were also conducted in order to optimize data sampling otherwise collected through logbooks provided to the fishermen.

Not all information could be collected for each of the franciscanas incidentally caught and, therefore, sample sizes varied among variables of interest. The standard length of the franciscanas $(\mathrm{N}=180)$ was measured in a straight line following method of the American Society of Mammalogy (1961). Whenever possible, franciscanas were also weighed $(\mathrm{N}=116)$. Teeth $(\mathrm{N}=124$ individuals $)$ and gonad samples $(\mathrm{N}=137)$ were collected and preserved dry and in formalin $10 \%$, respectively.

\section{Age determination}

Age estimates were obtained by counting the growth layer groups (GLGs) in thin, longitudinal sections of teeth. The teeth were decalcified in nitric acid or in RDO (a commercial mixture of acids) and sectioned on a freezing microtome. The 15-20 $\mu \mathrm{m}$ sections were stained with Mayer's haematoxylin and mounted in microscope slides with Canadian balsam or in glycerin. Poor and off-centre sections were discarded in favour of new preparations. Three independent readers counted the number of growth layer groups in the dentine and cementum. Whenever counts differed among readers, the sections were reexamined and the best counting was determined on a consensus basis. One GLG was assumed to represent one year of age (Pinedo \& Hohn, 2000).

\section{Reproductive status}

Male sexual maturity status was determined after histological analysis of the testes according to Hohn et al. (1985) as follows: (i) immature-seminiferous tubules containing mainly spermatogonias. Abundant interstitial tissue between the seminiferous tubules and lumen totally closed; (ii) pubertal-seminiferous tubules containing spermatogonias and spermatocytes. Less interstitial tissue present between the seminiferous tubules than in immature animals. The lumen is partially opened; and (iii) mature-seminiferous tubules containing spermatogonias, spermatocytes, spermatids and, in many times, spermatozoa. Interstitial tissue is almost non-existent between the seminiferous tubules. The lumen is totally opened.

The determination of female reproductive status followed the criteria recommended by the International Whaling Commission (Perrin \& Donovan, 1984) after the macroscopic and histological analysis of the ovaries, uterus and mammary glands. Females with no corpora lutea (CL) or albicantia (CA) in the ovaries were classified as sexually immature. Females with at least one CL or CA in one ovary, denoting a past ovulation, were classified as sexually mature. Females were considered lactating if milk was detected in the mammary glands. The presence of a foetus in the uterus was used as criterion of pregnancy.

In order to increase the sample size of animals with known reproductive status for the habitat use analysis, dolphins for which the gonads could not be collected had their reproductive status determined indirectly based on the average age and length at sexual maturity and their upper and lower limits for females (Danilewicz, 2003) and males (Danilewicz et al., 2004). For the females, individuals smaller than $130.0 \mathrm{~cm}$ in length or aging 2 years or less were considered sexually immature, whereas any animal larger than $150.0 \mathrm{~cm}$ in length or aging 5 years or more was considered sexually mature. Likewise for the males, any individual smaller than $115.0 \mathrm{~cm}$ in length or aging up to 1 year was considered immature, whereas animals larger than $135.0 \mathrm{~cm}$ in length or aging 5 years or more were considered sexually mature. For both sexes, animals for which the gonads could not be collected and which were within these upper and lower limits were not included in the analysis.

\section{Habitat use analysis}

The water depth of each incidentally caught franciscana was determined with an echobathymeter, otherwise estimated with the assistance of a nautical chart in cases where franciscanas were caught by boats not having an echobathymeter.

Although floating gillnets are utilized in the study area, the great majority of the franciscana incidental catches occurred in fixed bottom-set gillnets. In this manner, the water depths reported in this paper reflect accurately the depths used by the dolphins.

On some occasions, the water depth of incidental catches was not accurately recorded rather it was allocated to bin intervals of $5 \mathrm{~m}$. In such cases, the depth was arbitrarily considered as the mid-point of that interval. For example, when the recorded depth was within the $20-25 \mathrm{~m}$ interval, the depth of $22.5 \mathrm{~m}$ was considered in the analysis.

The stratification of Rio Grande do Sul in southern and northern coasts was based in the fishing grounds of vessels 
operating from Rio Grande and Tramandaí/Imbé, respectively. The Rio Grande commercial fleet operates mainly from the lighthouse of Sarita $\left(32^{\circ} 38^{\prime} S\right)$ to the lighthouse of Mostardas ( $\left.31^{\circ} 13^{\prime} S\right)$ (Secchi et al., 1997a), whereas vessels from Tramandaí operate mainly around Solidão lighthouse $\left(30^{\circ} 41^{\prime} \mathrm{S} 50^{\circ} 30^{\prime} \mathrm{W}\right)$ and Capão da Canoa $\left(29^{\circ} 44^{\prime} \mathrm{S} 50^{\circ} \mathrm{oo}^{\prime} \mathrm{W}\right)$ (Moreno et al., 1997; Ott, 1998) (Figure 1).

The sex-ratio for each stratum was calculated as:

$$
r=m / f
$$

where $r$ is the ratio of males to females in the sample, $m$ is the number of males and $f$ is the number of females.

Since information concerning the fishery effort by depth in Rio Grande do Sul was not incorporated in the present analyses, conclusions about habitat preference within a group (e.g. sex and reproductive status) could not be carried out. However, comparisons between groups (e.g. males versus females; mature versus immature animals) in a same area are permitted.

Differences in the mean water depth between gender and reproductive status were tested using Student's $t$-test or Mann-Whitney rank sum test. Age and size-related spatial segregation according to water depth was tested by fitting a linear regression and verifying whether the resulting slope $b$ was different or equal to o. Differences between observed and expected sex-ratio were examined with Chi-squared goodness-of-fit tests. A level of significance $\alpha=0.05$ was considered for all tests.

\section{RESULTS}

Information on the depth of franciscana by-catch location off Rio Grande do Sul state coast allowed us to analyse the depth-related distribution pattern according to dolphin's age, length, gender and reproductive status.

\section{Sex-ratio}

The sex-ratio calculated for franciscanas incidentally caught on the northern and southern coast of Rio Grande do Sul is presented in Table 1 . The observed sex-ratio of foetuses did

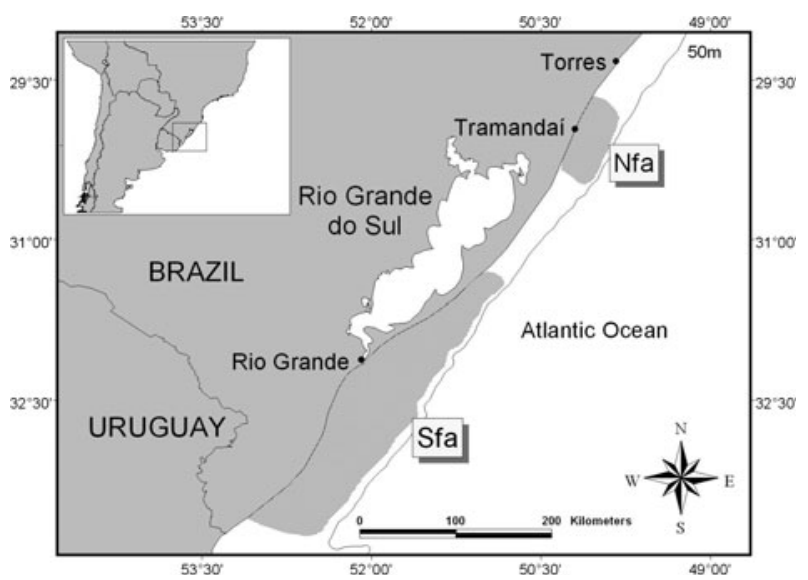

Fig. 1. Map of the study area, showing the northern fishery area (Nfa) and southern fishery area (Sfa) discussed in the text.
Table 1. Sex-ratio of incidentally caught franciscanas, Pontoporia blainvillei, on the northern coast (RSN) and southern coast (RSS) of Rio Grande do Sul. Values significantly different from 1 are symbolized as * $(\alpha=0.05)$.

\begin{tabular}{lccll}
\hline Sample & Females & Males & Sex-ratio & $\chi^{2}$ \\
\hline Foetuses & 6 & 8 & 1.32 & 0.29 \\
By-catches southern coast & 89 & 106 & 1.19 & 1.48 \\
By-catches northern coast & 19 & 37 & 1.92 & $5.79^{*}$ \\
\hline
\end{tabular}

not differ from the expected 1:1. On the northern coast, the sex-ratio was biased towards males in all length intervals (Figure 2).

On the southern coast, the proportions of sexually mature females and males were $37.5 \%$ and $42.1 \%$, respectively. On the northern coast, the proportion was quite similar for mature females $(36.6 \%)\left(\chi^{2}=0.82,0.25<P<0.50\right)$, but significantly smaller $(11.9 \%)$ for mature males $\left(\chi^{2}=37.42, P<\right.$ 0.001).

Operational sex-ratio ${ }^{1}$ of franciscanas bycaught in the southern area (1.16 mature male for each mature female) did not differ from unity $\left(\chi^{2}=0.46, P=0.50, N=78\right)$. In the northern area, operational sex-ratio was biased towards females (2.3 mature females to each mature male), although this ratio was not significantly different from unity due to the small sample size of mature animals $\left(\chi^{2}=1.60,0.10<\right.$ $P<0.25, \mathrm{~N}=10$ ).

\section{Water depth and gender}

There was no significant difference between the mean depth where males $($ mean $=21.7 \mathrm{~m})$ and females $($ mean $=21.1 \mathrm{~m})$ ( $\mathrm{t}=0.61, \mathrm{df}=134, P=0.55)$ were caught. Depth of the by-catch locations ranged from 6 to $35 \mathrm{~m}$ for males and from 10 to $35 \mathrm{~m}$ for females. Similarly, when data were analysed by region, no differences were found in the mean depth of by-catch between males $($ mean $=23.0 \mathrm{~m}$ ) and females $($ mean $=20.9 \mathrm{~m})$ from the southern area $(\mathrm{t}=1.61$, $\mathrm{df}=78, P=0.11)$, and between males $($ mean $=18.1 \mathrm{~m})$ and females $($ mean $=21.7 \mathrm{~m})$ from the northern area $(\mathrm{t}=1.9$, $\mathrm{df}=26, P=0.07)$. Depth-related sex-ratio did not differ from 1 (Table 2).

\section{Water depth and age}

The slope of the linear regression to test correlation between age of males and water depth of by-catch is not significant ( $b=0.087, P=0.85$, IC 95\% $=-0.85-1.02$ ) (Figure 3 ). The slope was significantly negative for females $(b=-0.83, P=$ 0.044 , IC $95 \%=-1.63--0.023$ ) (Figure 4). However, this trend was clearly produced due to the influence of the low depth of by-catch of the two oldest animals: 10 and 11 year old females bycaught in water depths of 14 and $12 \mathrm{~m}$, respectively. After excluding these two animals, no significant trend was detected $(\mathrm{b}=-0.56, P=0.31$, IC $95 \%=-1.66-0.53)$.

${ }^{1}$ Operational sex-ratio (sensu Emlem \& Oring, 1977) is the ratio of sexually mature males to the sexually mature females. 


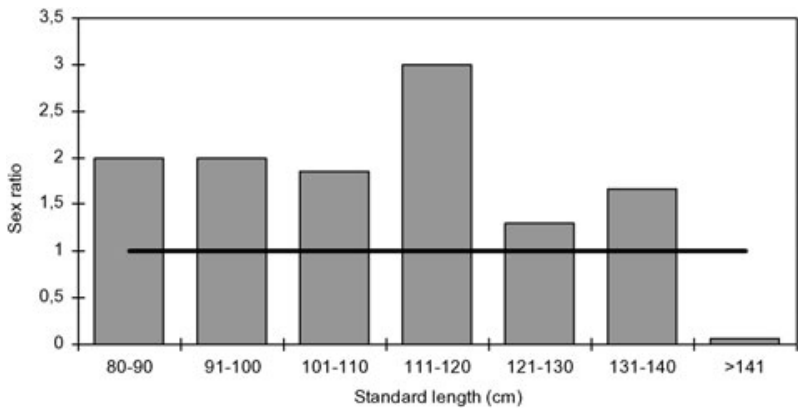

Fig. 2. Sex-ratio of franciscanas, Pontoporia blainvillei, incidentally caught in the northern coast of Rio Grande do Sul. The dark line represents the sex-ratio 1:1. Values higher than 1 denote a male-biased sex-ratio. Largest male in the sample is $135.5 \mathrm{~cm}$.

\section{Water depth and standard length}

The slope of the linear regression to test correlation between water depth and franciscana standard length was not significant either in males $(b=0.10, P=0.70,95 \% \mathrm{CI}=-0.42-$ 0.63) (Figure 5) or in females $(b=-0.056, P=0.28,95 \%$ $\mathrm{CI}=-0.16-0.046)($ Figure 6)

\section{Water depth and reproductive status}

In order to test whether or not pregnancy influenced distribution of females, we compared the depth at the location of by-catch of pregnant (mean $=19.2 \mathrm{~m}, \mathrm{~N}=10$ ) and nonpregnant mature females $($ mean $=21.5 \mathrm{~m}, \mathrm{~N}=8)$. Difference in water depth of the by-catch between these two groups was non-significant $(\mathrm{t}=-0.84, \mathrm{df}=12, P=0.41)$. In addition, to investigate the influence of the stage of the gestation in the habitat use, we studied the relationship between foetus length and depth and again no significant difference in the slope of the linear regression between these variables was found $\left(b=0.031, P=0.73\right.$, CI $95 \%=-0.17-0.23, \quad r^{2}=$ 0.015).

Distribution of franciscanas of different reproductive status does not change according to water depth. In the southern area, depth of occurrence of immature $($ mean $=25.1 \mathrm{~m})$ and mature males (mean $=24.6 \mathrm{~m}$ ) is not significantly different $(\mathrm{t}=0.38, \mathrm{df}=52, P=0.70)$. Similarly, no significant difference was found in the mean water depth of by-catch between immature $($ mean $=22.8 \mathrm{~m}$ ) and mature females $($ mean $=20.7 \mathrm{~m})(\mathrm{t}=0.85, \mathrm{df}=52, P=0.40)$.

Water depth of the by-catch was recorded only for six lactating females. In order to increase sample size and allow for a comparison with non-lactating mature females, we assumed

Table 2. Absolute frequency of male and female franciscanas, Pontoporia blainvillei, stratified by water depth intervals (in metres).

\begin{tabular}{lccll}
\hline Depth interval & Males & Females & Sex-ratio & $\chi^{2}$ \\
\hline $6-10$ & 2 & 2 & 1 & 0.0 \\
$11-15$ & 10 & 12 & 0.84 & 0.18 \\
$16-20$ & 20 & 12 & 1.64 & 2.0 \\
$21-25$ & 36 & 24 & 1.49 & 2.4 \\
$26-30$ & 22 & 14 & 0.64 & 1.78 \\
$31-35$ & 4 & 5 & 0.82 & 0.11 \\
Total & 94 & 69 & & \\
\hline
\end{tabular}

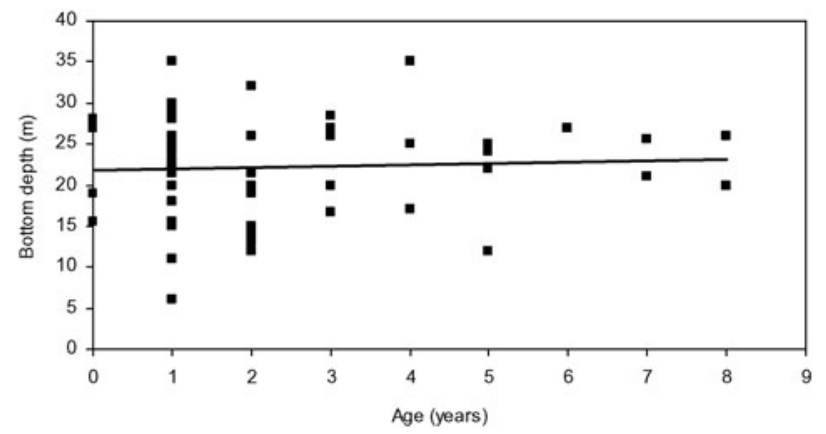

Fig. 3. Relationship between age and bottom depth at the locality of the incidental catch for male franciscanas, Pontoporia blainvillei, in Rio Grande do Sul $(\mathrm{N}=61)$.

that by-catch location of six calves presumably still suckling, according to their small lengths (less than $95.0 \mathrm{~cm}$; see Brownell, 1984), represents the distribution of their mothers. A significant difference was detected for the mean depth of by-catch between lactating $($ mean $=25.0 \mathrm{~m})$ and non-lactating females $($ mean $=18.8 \mathrm{~m})(\mathrm{t}=2.84, \mathrm{df}=22, P=0.0095)$.

\section{DISCUSSIDN}

This study suggests that there is no reproductive status, gender, or age-related segregation of franciscanas according to water depth off Rio Grande do Sul. Individuals of all sizes and ages utilize nearly the entire depth-range of the surveyed area, indicating that franciscana occurrence in deeper waters is not limited by body size or age. In Uruguay, despite changes in the fishing grounds from the 1969-1975 period (concentrated in water depths ranging from 20 to $30 \mathrm{~m}$ ) to the $1980-1982$ period (concentrated in water depths of 6 to $15 \mathrm{~m}$ ) no difference in the age-frequency of bycaught animals was also observed between the two periods (Praderi et al., 1989; Pinedo, 1994).

In a previous study in Rio Grande do Sul, based on a smaller sample, Secchi et al. (1997b) found differences in the mean depth of by-catch between males $(31 \mathrm{~m})$ and females $(22 \mathrm{~m})$. Rosas et al. (2002) also suggested that a certain degree of spatial segregation may exist for the franciscanas in Paraná/southern São Paulo, where the immature utilize shallower waters than adult individuals. However, conclusions from both studies are based on limited sample sizes

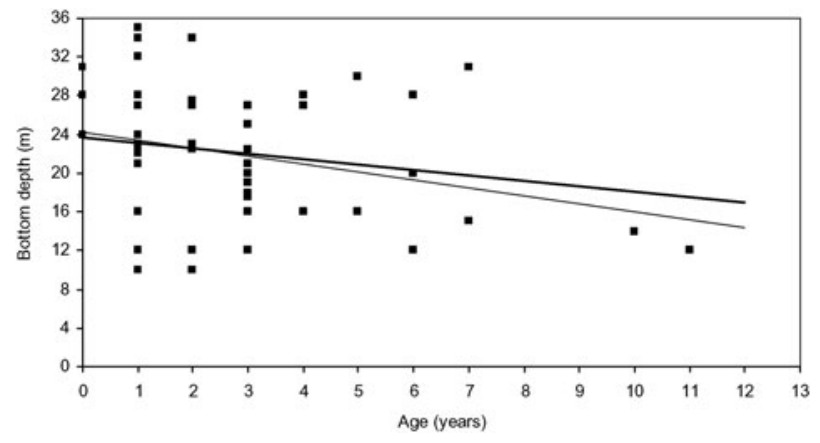

Fig. 4. Relationship between age and bottom depth at the locality of the incidental catch for female franciscanas, Pontoporia blainvillei, in Rio Grande do Sul $(\mathrm{N}=53)$. The thinner and the thicker line represent the slopes with and without the two oldest females, respectively. 


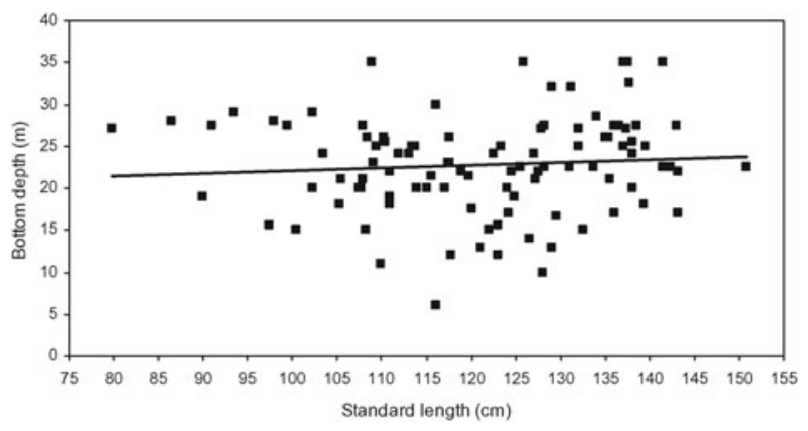

Fig. 5. Relationship between standard length and bottom depth at the locality of the incidental catch of male franciscanas, Pontoporia blainvillei, in Rio Grande do Sul $(\mathrm{N}=107)$.

from by-catches $(\mathrm{N}<50)$ and the results should be viewed with some caution. It is important to note that the same data used by Secchi et al. (1997b) were incorporated in the present analysis.

The franciscana lives in small groups, usually $1-6$ animals (Crespo et al., 1998; Bordino et al., 1999), and preys mainly upon coastal demersal fish and squids (Bassoi, 1997; Rodríguez et al., 2002). The species inhabits a moderately narrow strip of coast in the south-western Atlantic. This strip initiates in very coastal waters, just beyond the surf zone, as documented by some incidental catches and a recent aerial survey (Danilewicz, unpublished data). However, the offshore limit of the franciscana distribution strip is not well defined. The maximum bottom depth of by-catch of a franciscana in this study is $35 \mathrm{~m}$. Nevertheless, this result is influenced by the fishery effort and must not be seen as the isobath limit for the species. At least in Rio Grande do Sul, some records in waters up to 55-60 m deep have been made (Danilewicz, personal observation), though the density in these areas is likely to be very low.

It has been documented that franciscanas move inshore in spring and summer for feeding, mating and calving in Anegada Bay, Argentina (Bordino et al., 1999). The authors related the use of the bay's coastal waters by calves and adults during the reproductive period to the protection from predation in a food-rich habitat. In our study site-a distinct open ocean habitat without major tide influence-we were not able to corroborate the same findings. Also, pregnant females do not seem to change their habitat related to bottom depth as a response to the progress of gestation.

Shallow waters have been considered as a synonym of a protective environment for cetaceans. This proposition is

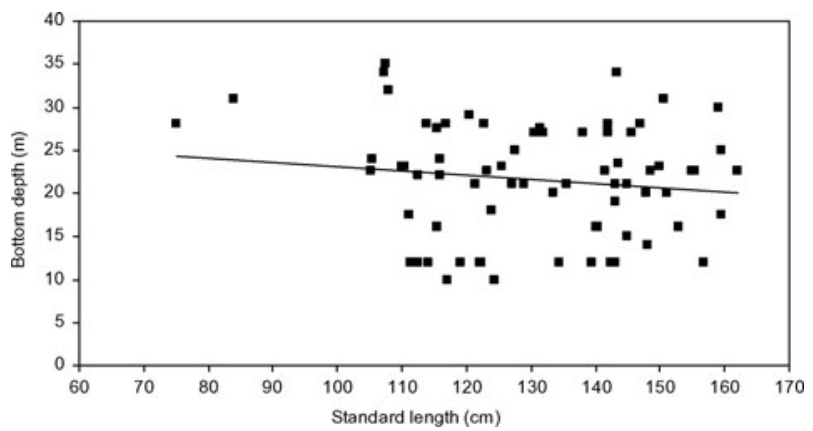

Fig. 6. Relationship between standard length and bottom depth at the locality of the incidental catch of female franciscanas, Pontoporia blainvillei, in Rio Grande do Sul $(\mathrm{N}=72)$. usually based on the consideration that encounters with predators are less frequent in these areas. The use of coastal and shallow habitats by odontocetes as a strategy to avoid encounters with predatory sharks has been proposed for Hawaiian spinner dolphins, Stenella longirostris (Norris \& Dohl, 1980) and bottlenose dolphins, Tursiops truncatus (Wells et al., 1987). Mann et al. (2000) have found higher calf survivorship in female bottlenose dolphins that raised their calves in shallow waters. Nevertheless, the relationship between water depth and shark predation risk is not completely understood and may be complex and highly variable geographically (Heithaus, 2001). In a comprehensive study on habitat use of bottlenose dolphins in Shark Bay, Australia, Heithaus \& Dill (2002) demonstrated a trade-off between energy intake and predation risk. In that region, habitat characteristics and shark density turn shallow waters into a relatively more risky ambient in some periods of the year, with the dolphins selecting deeper waters to rest.

Moreover, depending on the shark species predation behaviour, coastal turbid waters may represent a more dangerous habitat than translucent pelagic waters. Excessively shallow waters may impose limitations on the echolocation effectiveness and on the dolphin escaping. Franciscanas are predated both by sharks and killer whales (Praderi, 1985; Ott \& Danilewicz, 1998; Santos \& Netto, 2005). Regarding the two shark species known to predate on franciscanas (Praderi, 1985), the sevengill shark, Notorhynchus cepedianus, prefer turbid waters while the tiger shark, Galeocerdo cuvieri, camouflage efficiently against dark backgrounds. In this manner, the turbid coastal waters of Rio Grande do Sul and Uruguay may not be so advantageous for franciscana female-calf pairs in terms of predation avoidance in order to make them restrict their activities exclusively to this habitat.

On many occasions, segregation may be revealed not only by the differential use of space, but also by differences in the diet (Bowyer, 2004). The franciscana diet has been studied in many areas with no evidence for significant differences between sexes and age-classes, with the exception of shrimps that are important only in the diet of juvenile dolphins (Pinedo et al., 1989; Ott, 1994; Bassoi, 1997; Rodriguez et al., 2002).

It is fundamental to be aware that the detection of sexual segregation is dependent on scale (Bowyer, 2004). Although our results reveal that in a large scale, franciscanas of different ages, sizes, gender and reproductive classes (for females) are homogeneously distributed according to water depth, the sexratio comparison between areas suggests that sexual segregation may occur on a smaller scale. Franciscanas are born in 1:1 sex-ratio (Brownell, 1984; Danilewicz, 2003). However, some study sites present remarkable exceptions. In the coast of Necochea and Claromecó, northern Argentina, Corcuera et al. (1994) recorded a sex-ratio deviated towards males (1.61 males for each female). In São Paulo, southeastern Brazil, a higher sex-ratio towards males (1.73) has been recorded (C. Bertozzi, personal communication).

The sex-ratio towards males for the franciscanas from the northern coast of Rio Grande do Sul may be effectively reflecting the real structure of the population in a small area or being caused artificially by methodological biases. Corcuera et al. (1994) commented that the sex-ratio biased to male franciscanas could be attributed to a greater difficulty of manipulation of the largest dolphins by the fishermen. The authors argued that on occasions when the researchers are not onboard, the 
fishermen could discard the larger animals and collect preferentially the smaller ones. Since the franciscana presents reversed sexual size dimorphism (RSSD) (i.e. females larger than males), this could cause an artificial increase in the number of males collected. Nevertheless, this hypothesis is rejected since the sex-ratio in the northern coast fishery ground is directed towards males even for juveniles, when the RSSD is low or even non-existent. Consequently, the sexratio deviated towards males on the northern coast may in fact reflect differences in the distribution patterns of males and females in Rio Grande do Sul.

Franciscana by-catch in Rio Grande do Sul is not sustainable (Kinas, 2002; Secchi et al., 2003a). It is agreed that management procedures in the fishery certainly need to be taken in the next few years. The information on the distribution of a particular species and the location of interactions with fisheries are necessary in making management decisions leading to the implementation of regulations. One possible management action for the franciscana problem could be the restriction of certain fishery grounds through the creation of a marine protected area. The results of the present study indicate that the available data do not allow the designing of a protected area in order to minimize the by-catches of a particular sex/reproductive class of franciscana (e.g. mature or pregnant females).

This study is a first attempt to shed some light on the habitat use patterns of this elusive dolphin in southern Brazil, but important aspects on this subject still remain to be understood. Although a habitat preference by water depth could not be noticed, it is plausible that some segregation or habitat preference exists by latitude or season. The achievement of a larger sample and a more accurate set of data (e.g. coordinates of the by-catch locality) jointly with refined information on the fishery effort in future analyses will improve our knowledge on the habitat use of franciscana dolphins.

\section{ACKNDWLEDGEMENTS}

We are very grateful to the fishermen from Rio Grande and Tramandaí/Imbé for their important cooperation with the franciscana projects during various years. We thank our many colleagues who participated in the collection and necropsies, including L. Fidelix, L. Dalla Rosa, G. Caon, L. Oliveira, X. Clay, C.C. Campos-Trigo, S. Nakashima, A. Zerbini, and numerous volunteers. Dr N.F. Fontoura has provided guidance, support and supervision in many steps of this study. Thanks also to N.L. Würdig, I.D. Pinto (CECLIMARUFRGS) and L. Barcellos (Director of the Museu Oceanográfico) for the constant logistical support and encouragement of the marine mammal research in southern Brazil C. Bertozzi very kindly allowed the citation of unpublished data. Financial supports for franciscana conservation projects have been given by the Cetacean Society International, Fundação $\mathrm{O}$ Boticário de Apoio à Natureza, The John and Catherine MacCarthur Foundation, the Yaqu Pacha Foundation, CNPq, United Nations Environmental Program and Whale and Dolphin Conservation Society. This article is part of D. Danilewicz's MSc thesis and the Coordenação de Aperfeiçoamento de Pessoal em Ensino Superior (CAPES) has granted him a graduate fellowship. E. R. Secchi has a scholarship provided by Brazilian Council for Research and Technological Development (CNPq, Process No. 305219/ 2008-1). The manuscript was improved by the comments of an anonymous referee. This paper is GEMARS communication No. 23.

\section{REFERENCES}

American Society of Mammalogy (1961) Standardized methods for measuring and recording data on the smaller cetaceans. Journal of Mammalogy 42, 471-476.

Bassoi M. (1997) Feeding of franciscana, Pontoporia blainvillei (Gervais and D'Orbigny, 1844), accidentally caught in coastal gillneting in southern Brazil. Bs dissertation. Universidade do Rio Grande, Rio Grande, Brazil.

Bordino P. (2002) Movement patterns of franciscana dolphin (Pontoporia blainvillei) in Bahia Anegada, Buenos Aires, Argentina. Latin American Journal of Aquatic Mammals 1, 71-76.

Bordino P., Thompson G. and Iñiguez M. (1999) Ecology and behaviour of the franciscana (Pontoporia blainvillei) in Bahía Anegada, Argentina. Journal of Cetacean Research and Management 1, 213-222.

Bowyer R.T. (2004) Sexual segregation in ruminants: definitions, hypotheses, and implications for conservation and management. Journal of Mammalogy 85, 1039-1052.

Brownell R.L. Jr (1984) Review of reproduction in platanistid dolphins. Report of the International Whaling Commission 6, 149-158.

Corcuera J., Monzon F., Crespo E.A., Aguilar A. and Raga J.A. (1994) Interactions between marine mammals and the coastal fisheries of Necochea and Claromecó (Buenos Aires Province, Argentina). Report of the International Whaling Commission 15, 283-290.

Cremer M.J. and Simões-Lopes P.C. (2005) The occurrence of Pontoporia blainvillei (Gervais \& d'Orbigny) (Cetacea, Pontoporiidae) in an estuarine area in southern Brazil. Revista Brasileira de Zoologia 22, 717-723.

Crespo E.A., Harris G. and González R. (1998) Group size and distribution range of the franciscana, Pontoporia blainvillei. Marine Mammal Science 14, 845-849.

Danilewicz D. (2003) Reproduction of female franciscana (Pontoporia blainvillei) in Rio Grande do Sul, southern Brazil. Latin American Journal of Aquatic Mammals 2, 67-78.

Danilewicz D., Claver J.A., Pérez Carrera A.L., Secchi E.R. and Fontoura N.F. (2004) Reproductive biology of male franciscanas (Pontoporia blainvillei) (Mammalia: Cetacea) from Rio Grande do Sul, southern Brazil. Fishery Bulletin 102, 581-592.

Emlem S.T. and Oring L.W. (1977) Ecology, sexual selection, and the evolution of mating systems. Science 197, 215-223.

Heithaus M.R. (2001) Predator-prey and competitive interactions between sharks (Order Selachii) and dolphins (Suborder Odontoceti): a review. Journal of Zoology 253, 53-68.

Heithaus M.R. and Dill L.M. (2002) Food availability and tiger shark predation risk influence bottlenose dolphin habitat use. Ecology 83, $480-491$.

Hohn A., Chivers S.J. and Barlow J. (1985) Reproductive maturity and seasonality of male spotted dolphins, Stenella attenuata, in the eastern tropical Pacific. Marine Mammal Science 1, 273-293.

IUCN (2008) IUCN Red List of Threatened Species: A Global Species Assessment. Gland, Switzerland and Cambridge, UK: IUCN Pontoporia blainvillei. Available from http://www.iucnredlist.org/ search/details.php/41761/all (accessed September 2008).

Kinas P.G. (2002) The impact of incidental kills by gillnets on the franciscana dolphin (Pontoporia blainvillei) in southern Brazil. Journal of Marine Science 70, 409-421. 
Mann J., Connor R.C., Barre L.M. and Heithaus M.R. (2000) Female reproductive success in bottlenose dolphins (Tursiops sp.): life history, habitat, provisioning, and group size effects. Behavioral Ecology 11, 210-219.

Moreno I.B., Ott P.H. and Danilewicz D. (1997) Análise preliminar do impacto da pesca artesanal costeira sobre Pontoporia blainville no litoral norte do Rio Grande do Sul, sul do Brasil. In Proceedings of the 2nd Workshop for the Coordination of Research and Conservation of Franciscana in the Southwestern Atlantic, Buenos Aires, Argentina, 1997, pp 31-41.

Norris K.S. and Dohl T.P. (1980) Behavior of the Hawaiian spinner dolphin, Stenella longirostris. Fishery Bulletin 77, 821-849.

Ott P.H. (1994) Estudo da ecologia alimentar de Pontoporia blainvillei (Gervais; D’Orbigny 1844) (Cetacea, Pontoporiidae) no litoral norte do Rio Grande do Sul, Sul do Brasil. BSc dissertation. Universidade Federal do Rio Grande do Sul, Porto Alegre, Brazil.

Ott P.H. (1998) Análise das capturas acidentais da toninha, Pontoporia blaivillei, no litoral norte do Rio Grande do Sul, sul do Brasil. MSc dissertation. Pontifícia Universidade Católica do Rio Grande do Sul, Porto Alegre, Brazil.

Ott P.H. and Danilewicz D. (1998) Presence of franciscana dolphins (Pontoporia blainvillei) in the stomach of a killer whale (Orcinus orca) stranded in southern Brazil. Mammalia 62, 605-609.

Ott P.H., Secchi E.R., Moreno I.B., Danilewicz D., Crespo E.A., Bordino P., Ramos R., Di Beneditto A.P., Bertozzi C., Bastida R., Zanelatto R., Perez J. and Kinas P.G. (2002) Report of the working group of fishery interactions. Latin American Journal of Aquatic Mammals 1, 55-64.

Perrin W.F. and Donovan G.P. (1984) Report of the workshop. Report of the International Whaling Commission 6, 1-24.

Pinedo M.C. (1994) Impact of incidental fishery mortality on the age structure of Pontoporia blainvillei in southern Brazil and Uruguay. Report of the International Whaling Commission 15, 261-264.

Pinedo M.C. and Hohn A. (2000) Growth layer patterns in teeth from the franciscana, Pontoporia blainvillei: developing a model for precision in age estimation. Marine Mammal Science 16, 1-27.

Pinedo M.C., Praderi R. and Brownell R.L. Jr (1989) Review of the biology and status of the franciscana, Pontoporia blainvillei. In Perrin W.F., Brownell R.L. Jr., Kaya Z. and Jiankang L. (eds) Biology and conservation of river dolphins. Occasional Papers of the IUCN Species Survival Commission, pp. 46-51.

Praderi R. (1985) Relaciones entre Pontoporia blainvillei (Mammalia: Cetacea) e tiburones Selachii) de aguas Uruguaias. Comunicaciones de Zoologia del Museo de Historia Natural de Montevideo 11, 1-19.

Praderi R. (1986) Comentarios sobre la distribución de Pontoporia blainvillei en aguas del Rio de La Plata. In Proceedings of the 1st Reunión de Trabajo de Expecialistas en Mamiferos Acuaticos de América del Sur, Buenos Aires, Argentina, 1984, pp. 206-214.

Praderi R., Pinedo M.C. and Crespo E.A. (1989) Conservation and man agement of Pontoporia blainvillei in Uruguay, Brazil and Argentina. In Perrin W.F., Brownell R.L. Jr., Kaya Z. and Jiankang L. (eds) Biology and conservation of river dolphins. Occasional Papers of the IUCN Species Survival Commission, pp. 52-56.

Rodriguez D., Rivero L. and Bastida R. (2002) Feeding ecology of the franciscana (Pontoporia blainvillei) in marine and estuarine waters of Argentina. Latin American Journal of Aquatic Mammals 1, 77-94.
Rosas F.C.W., Monteiro-Filho E.L.A. and Oliveira M.R. (2002) Incidental catches of franciscana (Pontoporia blainvillei) on the southern coast of São Paulo state and the coast of Paraná state, Brazil. Latin American Journal of Aquatic Mammals 1, 161-167.

Santos M.C.O. and Netto D.F. (2005) Killer whale (Orcinus orca) predation on a franciscana dolphin (Pontoporia blainvillei) in Brazilian waters. Latin American Journal of Aquatic Mammals 4, 69-72.

Secchi E.R., Zerbini A.N., Bassoi M., Dalla Rosa L., Moller L.M. and Rocha-Campos C.C. (1997a) Mortality of franciscanas, Pontoporia blainvillei, in coastal gillnetting in southern Brazil. Report of the International Whaling Commission 47, 653-658.

Secchi E.R., Dalla Rosa L., Bassoi M. and Barcellos L. (1997b) Uma alternativa para minimizar o impacto da pesca costeira de emalhe sobre a população de toninhas, Pontoporia blainvillei (Cetacea, Pontoporiidae), no sul do Brazil. In Proceedings of the 7 th Congresso Latino-Americano sobre Ciências do Mar, Santos, SP, 1997. Associação Latino-Americana dos Profissionais de Ciências do Mar, pp. $428-429$.

Secchi E.R., Ott P.H. and Danilewicz D. (2003a) Effects of fishing by-catch and the conservation status of the franciscana dolphin, Pontoporia blainvillei. In Gales N., Hindell M. and Kirkwood R. (eds) Marine mammals: fisheries, tourism and management issues. Collingwood, Australia: CSIRO Publishing, pp. 174-191.

Secchi E.R., Danilewicz D. and Ott P.H. (2003b) Applying the phylogeographic concept to identify Franciscana dolphin stocks: implications to meet management objectives. Journal of Cetacean Research and Management 5, 61-68.

Secchi E.R., Kinas P.G. and Muelbert M. (2004) Incidental catches of franciscana in coastal gillnet fisheries in the Franciscana Management Area III: period 1999-2000. Latin American Journal of Aquatic Mammals 3, 61-68.

Secchi E.R. (2006) Modelling the population dynamics and viability analysis of franciscana (Pontoporia blainvillei) and Hector's dolphins (Cephalorynchus hectori) under the effects of bycatch in fisheries, parameter uncertainty and stochasticity. Doctoral thesis, University of Otago. Dunedin, New Zealand.

Siciliano S., Di Beneditto A.P. and Ramos R.M.A. (2002) A toninha, Pontoporia blainvillei (Gervais \& d'Orbigny, 1844) (Mammalia, Cetacea, Pontoporiidae), nos estados do Rio de Janeiro e Espírito Santo, costa sudeste do Brasil: caracterizações dos habitats e fatores de isolamento das populações. Boletim do Museu Nacional.(Zoologia) 476, 1-15.

and

Wells R.S., Scott M.D. and Irvine A.B. (1987) The social structure of free-ranging bottlenose dolphins. In Enoways H.H. (ed.) Current mammalogy. Volume 1. New York: Plenum Press, pp. 247-305.

\section{Correspondence should be addressed to:}

D. Danilewicz

Grupo de Estudos de Mamíferos Aquáticos do Rio Grande do Sul (GEMARS)

Rua Felipe Neri, 382/203, Porto Alegre 90440-150, Brazil email: daniel.danilewicz@gmail.com 